\title{
Assessment of microbiological quality of some drinks sold in the streets of Dhaka University Campus in Bangladesh
}

\author{
Mahbub Murshed Khan ${ }^{1}$, Md Tazul Islam², Mohammed Mehadi Hassan Chowdhury ${ }^{3 *}$ and Sharmin Rumi Alim ${ }^{1}$
}

\begin{abstract}
Background: Various kinds of fruit juices and sherbets sold by the street vendors are widely consumed in Dhaka city. These street vended fruit juices and sherbets are usually high in microbial loads. So, the present study was undertaken to assess the microbiological load, possible risk factors and identity of freshly squeezed juices and sherbets and their safety for human consumption in terms of pathogens.

Result: For the study purpose papaya juice, sugarcane juice, tukmaria sherbet, lemon sherbet and wood apple sherbet were taken as samples. The study showed a high microbial load in the drinks. The range of average total viable count (microbial load) and total coliforms were $7.7 \times 10^{3}-9 \times 10^{8} \mathrm{cfu} / \mathrm{ml}$ and $210-1100 \mathrm{cfu} / 100 \mathrm{ml}$, indicated the heavy presence of microorganisms in all the drinks analyzed in this study. The study revealed that tukmaria sherbet was most contaminated with a count of $9 \times 10^{8} \mathrm{cfu} / \mathrm{ml}$. The least contamination was observed in lemon sherbet. A count of $1.98 \times 10^{6} \mathrm{cfu} / \mathrm{ml}$ was observed in papaya juice and $3.4 \times 10^{5} \mathrm{cfu} / \mathrm{ml}$ was in wood apple sherbet. Total coliforms were present in all samples and average count for total coliforms was high in tukmaria sherbets than others. Various pathogenic species of bacteria such as Proteus sp., Enterobacter sp, E. coli, Shigella sp, Citrobacter sp, Vibrio sp, Yersinia sp and Hafnia sp were isolated from the juices and sherbets. Unhygienic water for dilution, dressing with ice, prolonged use without refrigeration, insanitary surroundings, raw materials, chemical properties, equipment, fruit flies and airborne dust are the risk factors of contamination.
\end{abstract}

Conclusion: It was revealed that consumption of these street drinks were harmful for people. These drinks can cause various food borne illnesses. People should avoid these drinks.

Keywords: Dhaka city; Fruit juice; Sherbet; Pathogen; Food borne illness

\section{Background}

In developing countries, various kinds of drinks sold by the street vendors are widely consumed by millions of people. These drinks are available in metropolitan and other cities of Bangladesh. In Bangladesh, the drinks usually consumed by the people at the streets or from roadside shops are various carbonated soft drinks, tea, coffee, fruit juices and sherbets. But the major drinks sold by the street vendors and found to consume by the people at the street are various kinds of fruit juices and sherbets. According to FAO, street food is a food

\footnotetext{
* Correspondence: md.mehadihassanchy@yahoo.com

${ }^{3}$ Department of Microbiology, Noakhali Science and Technology University, Noakhali, Bangladesh

Full list of author information is available at the end of the article
}

obtained from a street side vendor, often from a makeshift or portable stall (FAO 2007).

During summer season (during the months of March through August) a huge section about of the population of all income and age groups consumes these fresh pressed and squeezed juices and sherbets (Ahmed et al. 2009). These drinks are sold all the year round except winter season. Unpasteurized juices are preferred by the consumers because of the "fresh flavor" attributes and low cost. They are simply prepared by mechanically squeezing fresh fruits or may be extracted by water. The final product is an unfermented, clouded, untreated drink, ready for consumption. The drinks are nutritious for man. These are also good medium for the growth of many microorganisms some of which may be pathogenic to man. The pathogenic organism can cause various 
food borne diseases. Consumption of fresh fruit juices are increasing day by day. In addition to their increasing popularity in consumption patterns, fresh fruits and vegetables have also become increasingly important vehicles in food borne disease statistics (Sivapalasingam et al. 2004).

Consumption of fresh fruits and their juice provides potential health benefits to the general population (Alothman et al. 2009). Juices are fat-free, nutrient dense beverages that are rich in vitamins, minerals and naturally occurring phytonutrients that contribute to good health. It is good for health only when it is free from pathogenic microorganisms.

Contamination of food products can result in many health problems ranging from mild bloating and gas to serious incidents of food poisoning and dehydration. Unsafe and non hygienic fruits consumptions cause serious outbreaks of food borne illness (Sivapalasingam et al. 2004). There have been some notable outbreaks of illness in recent years that demonstrate the increasingly important role of fresh fruits and vegetables in food borne disease (Parish 1997; Sandeep et. al. 2001). There are several reports of illnesses due to the food borne diseases associated with the consumption of fruit juices at several places around the globe (Mosupye and Holy 2000; Muinde and Kuria 2005; Chumber et al. 2007). Usually raw materials, equipments, hand of the handlers, containers etc. are responsible for contamination. Contamination from raw materials and equipments, additional processing conditions, improper handling, prevalence of unhygienic conditions contributes substantially to the entry of bacterial pathogens in juices prepared from these fruits or vegetables (Oliveira et al. 2006; Nicolas et al. 2007). Water used for juice preparation can be a major source of microbial contaminants such as total coliforms, fecal coliforms, fecal streptococci etc. (Tasnim et al. 2010).

Street vended fruit juices and sherbets are found to sell in almost all areas of Dhaka city. There is a high demand of fresh fruit juices and sherbets in Dhaka city. Most of the time consumers are not conscious about the safety, quality, and hygiene of the drinks. It can be potential factor for food borne diseases. In view of the threat posed by the bacterial pathogens in street vended drinks and the flourishing demands of these drinks, the present study was undertaken to assess the bacteriological load and identity of freshly squeezed juices and sherbets and their safety for human consumption in terms of bacterial pathogens.

\section{Methods}

\section{Sample collection}

Two different types of drinks were taken as sample for the study purpose; these were 1) Fruit juice and 2)
Sherbet. There were two varieties of fruit juices namely papaya juice and sugarcane juice, and three types of sherbets namely tukmaria sherbet, lemon sherbet and wood apple sherbet. 3 samples of each type, total 15 samples were collected for test. The drinks were collected in sterile containers from the different vendors of five different places of Dhaka University Campus. The vendors were the drink and juice producers and they produced these in their makeshift stalls with unhygienic raw materials such as water, ice, syrups etc. and environment. The containers were kept in ice-boxes and transported to the laboratory.

\section{Sample processing}

The samples were in liquid form, so further processing was not required. One $\mathrm{ml}$ of liquid sample was taken and transferred into sterilized cotton plugged test tubes containing $9 \mathrm{ml}$ of $0.1 \%$ peptone water. Then they were mixed thoroughly by shaking 20 times. This time the solution was allowed to stand for 5-10minutes.Thus initial dilution of homogenate was prepared and from this homogenization further serial dilution were prepared.

\section{Bacteriological studies}

Pour plate method was used for the determination of total viable count using total plate count agar for water. This media is unique and nonselective to count bacteria and fungi. The samples were diluted at 10 fold dilution up to $10^{-6}$ according American public Health Association (APHA) sample dilution guidelines (APHA 1992). Two plates from every dilution for each temperature at $(36 \pm 2)^{\circ} \mathrm{C}$ for $(44 \pm 4)$ hrs for bacteria and $(22 \pm 2)^{\circ} \mathrm{C}$ for $(68 \pm 4)$ hrs for yeast \& molds were incubated. To identify the isolated bacteria; cultural, morphological and biochemical characteristics were studied carefully by using "Bergey's Manual of Determinative Bacteriology", 9th Ed. (Holt et al. 1994). Different types of selective agar were used for isolation and identification of bacterial colonies using streak plate method. The instructions for using of media were followed by guidelines of producing company. MacConkey agar was used to isolate Gram-negative enteric bacteria. To isolate and differentiate between Shigella sp. and Salmonella sp. SS agar was used because it was a differential media. TCBS agar was used as a selective media to isolate Vibrio spp. EMB (Eosin methylene blue) agar was used for the isolation of E.coli as a selective medium for E.coli and Proteus. The bacterial colonies grown on different types of medium were collected and maintained in Nutrient slant agar for further analysis. Some biochemical tests such as Kliger's Iron Agar (KIA) test, Motility test, Imvic test, Indole test, Urea (MIU), test Catalase and Oxidase tests were performed for the identification of bacterial isolates. MPN method is used for the quantitative estimation for 
coliforms using three test tubes where inoculums size were 10, 1, $0.1 \mathrm{ml}$. MacConkey broth and BGLB (Brilliant green lactose broth) were used in this experiment (APHA 1992).

\section{Results and discussion}

Colony morphology, phenotypic and biochemical traits of the isolates

After 24 hours of incubation, MPN test determined the estimation of total coliforms using MPN Chart. Yellow and green colonies on TCBS agar were primarily considered as Vibrio sp. Colorless, transparent, with a black center colonies in SS Agar were primarily considered as Salmonella sp. Green metallic sheen indicated the presence of E. coli on EMB plate. Biochemical tests gave the confirmation for the identification of bacterial isolates.

\section{Microbiological study}

From the study it was clear that all the juices and sherbets contain a significant amount of microorganisms. The average total viable count (microbial load) showed the presence of microbes in all the drinks analyzed in this study in the range of $7.7 \times 10^{3}-9 \times 10^{8} \mathrm{cfu} / \mathrm{ml}$. The study showed that tukmaria sherbet was most contaminated with a count of $9 \times 10^{8} \mathrm{cfu} / \mathrm{ml}$. Microbial load of sugarcane juice was $2.55 \times 10^{6} \mathrm{cfu} / \mathrm{ml}$. A count of $1.98 \times$ $10^{6} \mathrm{cfu} / \mathrm{ml}$ was observed in papaya juice and $3.4 \times$ $10^{5} \mathrm{cfu} / \mathrm{ml}$ was in wood apple sherbet. The least contamination was observed in lemon sherbet. The presence of total coilifroms in all drinks implied a negative relation with food quality and safety. The average total viable count and total coliforms count from the drinks were presented in the Table 1 and the isolates identified in the samples were listed in the Table 2 .

Ahmed et al. (2009) found a range of $3 \times 10^{2}$ to $9.6 \times$ $10^{8}$ microorganisms in freshly squeezed fruit juices sold in Dhaka City as well as Rashed et al. (2013) found a total microbial load within a range of $1.9 \times 10^{3}$ to $2.8 \times 10^{7} \mathrm{cfu} /$ $\mathrm{ml}$ and in the present study, microbial load recorded within the range of $10^{3}$ to $10^{8}$, which is quite similar to the findings of Ahmed et al. (2009) and Rashed et al. (2013) (Ahmed et al. 2009; Rashed et al. 2013).

Table 1 Average estimation of Total viable count and total coliforms from the drinks were given bellow

\begin{tabular}{llll}
\hline $\begin{array}{l}\text { Type of } \\
\text { drinks }\end{array}$ & $\begin{array}{l}\text { Number of } \\
\text { samples }\end{array}$ & $\begin{array}{l}\text { Average total viable } \\
\text { count (CFU/ml) }\end{array}$ & $\begin{array}{l}\text { Average MPN } \\
\text { (CFU/100 ml) }\end{array}$ \\
\hline Sugarcane juice & 3 & $2.55 \times 10^{6}$ & 290 \\
Tukmaria sherbet & 3 & $9 \times 10^{8}$ & 1100 \\
Lemon sherbet & 3 & $7.7 \times 10^{3}$ & 210 \\
$\begin{array}{l}\text { Wood apple } \\
\text { sherbet }\end{array}$ & 3 & $3.4 \times 10^{5}$ & 240 \\
$\begin{array}{l}\text { Papaya juice } \\
\text { S }\end{array}$ & 3 & $1.98 \times 10^{6}$ & 460 \\
\hline
\end{tabular}

Table 2 Identified bacterial isolates in sample drinks

\begin{tabular}{lllll}
\hline $\begin{array}{l}\text { Sugarcane } \\
\text { juice }\end{array}$ & $\begin{array}{l}\text { Tukmaria } \\
\text { sherbet }\end{array}$ & $\begin{array}{l}\text { Lemon } \\
\text { sherbet }\end{array}$ & $\begin{array}{l}\text { Wood apple } \\
\text { sherbet }\end{array}$ & $\begin{array}{l}\text { Papaya } \\
\text { juice }\end{array}$ \\
\hline Proteus & Proteus & Proteus & Proteus & Proteus \\
Enterobacter & Enterobacter & Yersinia & Hafnia & Enterobacter \\
E. coli & E. coli & & E. coli & E. coli \\
Shigella & Shigella & & & Shigella \\
Citrobacter & Salmonella & & & Vibrio \\
Vibrio & Vibrio & & & \\
& Aeromonas & & & \\
\hline
\end{tabular}

The highest contamination was recorded in tukmaria sherbet. It might be due to the raw materials used in this drink. Bacterial load in lemon sherbet was comparatively low. It may be due to low $\mathrm{pH}$ of lemon sherbet. The low $\mathrm{pH}$ of fruit juices greatly limits the number and the type of bacteria that can survive or grow at that $\mathrm{pH}$ (Prescott et al. 2002).

From the data presented in the current study, it could be concluded that the microbiological quality of most of the drinks collected from different areas of Dhaka University Campus were not satisfactory as fecal coliforms like E. coli, Enterobacter and other pathogens like Shigella, Vibrio were detected from the samples and all the samples contained higher load of microbes than the Gulf standard (Gulf Standards 2000) showed in table 3. The lack of knowledge on safe fruit juice preparation as well as the contamination source can contribute to the pathogens in prepared juices.

The presence of these microbes in food can be linked to a number of risk factors such as improper handling and processing, use of contaminated water during washing and dilution, cross contamination from rotten fruits and vegetables, or the use of dirty processing utensils like knife, flies and trays which was so relevant with the study of Khalil et al. (Khalil et al. 1994). This might also implicate the processing and rinsing water as possible sources of contamination of street foods sold by street vendors (Nwachukwu et al. 2008). The ice and water added during preparation were likely to provide possible sources of additional bacterial contamination (Bryan et al. 1998, 1992). Furthermore, these fruit juices were

Table 3 The recommended Microbiological standards for any fruit juices sold in the Gulf region (Gulf standards, 2000)

\begin{tabular}{llll}
\hline Test & $\begin{array}{l}\text { Total aerobic } \\
\text { bacterial count } \\
\text { (cfu/mL) }\end{array}$ & $\begin{array}{l}\text { Total coliforms } \\
\text { count }(\mathbf{c f u} / \mathbf{m L})\end{array}$ & $\begin{array}{l}\text { Yeasts and } \\
\text { molds } \\
\text { (cfu/mL) }\end{array}$ \\
\hline $\begin{array}{l}\text { Maximum count } \\
\text { anticipated }\end{array}$ & $5.0 \times 10^{3}$ & 10 & 100 \\
$\begin{array}{l}\text { Maximumcount } \\
\text { permitted }\end{array}$ & $5.0 \times 10^{4}$ & 100 & $1.0 \times 10^{3}$ \\
\hline
\end{tabular}


left in ambient temperature which may have led to the proliferation of contaminating bacteria resulting in increased bacterial counts (Bryan et al. 1977, 1992).

In the study various pathogenic bacteria were isolated from the juices and sherbets which may cause a serious outbreak in Bangladesh as like as USA where 21 fruit juice-associated outbreaks of illness were reported to the Centers for Disease Control and Prevention (CDC) from 1995 through 2005 (Vojdani et al. 2008). The presence of Salmonella was recorded in tukmaria sherbet. It was possible that Salmonella may have gained entry through water because vendors do not use boiled water and WASA water in Dhaka city is highly contaminated (Parveen et al. 2008) and this water is commonly used for diluting juices and washing utensils used for washing and preparing juices, alternately, the possibility of contamination of fruits through improperly treated irrigation water cannot be ruled out; survival and entry of enteropathogens including Salmonella have been shown in crops, irrigated with contaminated sewage (Ryu and Beuchat 1998). This organism causes typhoid and paratyphoid in human.

Present studies clearly indicated the presence of different types of fecal coliforms namely, Citrobacter, Enterobacter and Escherichia coli in all the drinks except lemon sherbet. The presence of coliforms in fruit juice is not allowed by safe food consumption standard (Andres et al. 2004). These organisms are highly pathogenic and may cause serious diseases in human beings. Citrobacter causes urinary tract infections, infections in gall bladder, middle ear etc. Enterobacter are responsible for urinary tract infections and hospital sepsis etc. Escherichia coli cause diarrhea, urinary infections, pyogenic infections and septicemia etc. (Ananthanarayan and Jayaram 1996; Falagas et al. 2007; Samonis et al. 2009). Shigella causes dysentery that result in the destruction of the epithelial cells of the intestinal mucosa in the cecum and rectum. Some strains produce the enterotoxin shiga toxin which causes hemolytic uremic syndrome (Koster et al. 1978). Several species of Vibrio are pathogenic (C. Michael 2010) and a significant number of fruit and vegetable borne outbreaks have been reported (Faruque et al. 1998). Most diseasecausing strains are associated with gastroenteritis, but can also infect open wounds and cause septicemia. Vibrio cholerae infects the intestine and increases mucous production causing diarrhea and vomiting which result in extreme dehydration and, if not treated, death (Howard-Jones 1984).

But to prevent such contamination in fruit juice drinks a Good Hygienic Practice (GHP) as defined in the Codex document on "General Principles of Food Hygiene" in combination with HACCP is the basis for safe food production (Codex Alimentarius, 1997). Government
Health Agencies must adopt measures to educate the vendors about food safety and hygienic practices and to develop a regular monitoring system. Robust traceability would greatly improve the epidemiological investigation, identification of causal or contributory factors and the control of suspected incidents of foodborne illness. There is a need for improved surveillance systems on food-borne pathogens, on food products and on outbreaks so that comparable data are available from a wider range of countries.

\section{Conclusions}

Low price and availability make the street vended juices and sherbets highly popular to general people. But these drinks will be beneficial if these are free from contamination. The current study revealed that all the studied fruit juices and sherbets had a higher microbial load than the specification set for fruit juices in some parts around the world. Regular monitoring of the quality of fruit juices for human consumption is recommended to avoid any future bacterial pathogen outbreak.

\section{Abbreviations}

C.F.U.: Colony forming unit; MPN: Most probable number; FAO: Food and agricultural organization.

\section{Competing interest}

The authors declare that they have no competing interest.

\section{Authors' contributions}

All the authors contributed equally to the preparation of this manuscript. All authors read and approved the final manuscript.

\section{Author details}

${ }^{1}$ Institute of Nutrition and Food Science, University of Dhaka, Dhaka, Bangladesh. ${ }^{2}$ Department of Food Technology and Nutrition Science, Noakhali Science and Technology University, Noakhali, Bangladesh. ${ }^{3}$ Department of Microbiology, Noakhali Science and Technology University, Noakhali, Bangladesh.

Received: 11 November 2014 Accepted: 12 February 2015

Published online: 19 April 2015

\section{References}

Ahmed MSU, Nasreen T, Feroza B, Parveen S (2009) Microbiological Quality of Local Market Vended Freshly Squeezed Fruit Juices in Dhaka City, Bangladesh. Bangladesh J Sci Ind Res 44(4):421-424

Alothman M, Bhat R, Karim AA (2009) Effects of radiation processing on phytochemicals and antioxidants in plant produce. Trends Food Sci Tech 20:201-212

American Public Health Association (APHA) (1992) Standard Methods for the Examination of Water and Wastewater, 18th edn. APHA, Washington, D.C

Ananthanarayan R, Jayaram Paniker CK (1996) Text Book of Microbiology, 5th edn. Orient Longman Limited, Chennai, pp 40-43, 250-261

Andres SC, Giannuzzi L, Zaritzky NE (2004) The effect of temperature on microbial growth in apple cubes packed in film and preserved by use of orange juice. Int J Food Sci Technology 39(9):927-933

Bryan FL (1977) Diseases transmitted by foods contaminated with wastewaters. J. Food Protect 40:45-56

Bryan FL, Teufel P, Riaz S, Roohi S, Qadar F, Malit Z (1992) Hazards and critical control points of vending operations at a railway station \& bus station in Palaitar. J Food Prot 55:534-541

Bryan FL, Michanie SC, Alvarez P, Paniagua A (1998) Critical control points of street vended foods in the Dominican Republic. J Food Prot 51:373-383 
Chumber SK, Kaushik K, Savy S (2007) Bacteriological analysis of street foods in Pune. Indian J Public Health 51(2):114-116

Codex Alimentarius (1997) Recomended International Code of Practice, General Principles of Food Hygiene. Supplement to volume 1 B. Joint FAO/WHO Food Standards Programme, FAO, Rome

Falagas ME, Rafailidis PI, Kofteridis D, Virtzili S, Chelvatzoglou FC, Papaioannou V, Maraki S, Samonis G, Michalopoulos A (2007) Risk factors of carbapenemresistant Klebsiella pneumoniae infections: a matched case-control study. J Antimicro Chemother 60:1124-1130

FAO (2007). The informal food sector. http://www.informalfood.unibo.it 2007-11-23.

Faruque SM, Albert MJ, Mekalanos JJ (1998) Epidemiology, genetics and ecology of oxigenic Vibrio cholerae. Microbiol Mol Biol Rev 62:1301-1314

Gulf Standards (2000) Microbiological Criteria for Foodstuffs-Part 1. GCC, Riyadh, Saudi Arabia

Holt JG, Krieg NR, Sneath PHA, Staley JT, Williams ST (1994) Bergey's manual of determinative bacteriology, 9th edn. Lippincott Williams \& Wilkins, Baltimore, MD

Howard-Jones N (1984) Robert Koch and the cholera vibrio: a centenary. BMJ 288 (6414):379-381. doi:10.1136/bmj.288.6414.379

Khalil K, Lindblom GB, Mazhar K, Kaijser B (1994) Flies and water as reservoirs for bacterial enteropathogens in urban and rural areas in and around Lahore Pakistan. Epidemiol Infect 113:435-444

Koster F, Levin J, Walker L, Tung KSK, Gilman RH, Rahaman MM, Majid A, Islam S, Williams RC (1978) Hemolytic uremic syndrome after shigellosis: relation to endotoxemia and circulating immune complexes. N Engl J Med 298:927-933

Hogan CM (2010) Bacteria, Encyclopedia of Earth, Sidney Draggan and C.J. Cleveland, National Council for Science and the Environment, NCSE, Washington DC

Mosupye FM, Holy AV (2000) Microbiological hazard identification and exposure assessment of street food vending in Johannesburg, South Africa. Int J Food Microbiol 61:137-145

Muinde OK, Kuria E (2005) Hygienic and sanitary practices of vendors of street foods in Nairobi, Kenya. Afr J Food Agri Nutri Dev 5(1):1-13

Nicolas B, Razack BA, Yollande I, Aly S, Tidiane OCA, Philippe NA, Comlan DS, Sababénédjo TA (2007) Street Vended foods improvement: contamination mechanism and application of food safety objective strategy: Critical Review. Pak J Nutr 6(1):1-10

Nwachukwu E, Ezeama CF, Ezeanya BN (2008) Microbiology of polyethylenepackaged sliced watermelon (Citrullus lanatus) sold by street vendors in Nigeria. Afr J Microbiol Res 2:192-195

Oliveira ACG, Seixas ASS, Sousa CP, Souza CWO (2006) Microbiological evaluation of sugarcane juice sold at street stands and juice handling conditions in São Carlos, São Paulo, Brazil. Cad Saude Publica 22(5):1111-1114

Parish ME (1997) Public health and non pasteurized fruit juices. Crit Rev Microbiol 23:109-119

Parveen S, Ahmed MSU, Nasreen T (2008) Microbial Contamination of water in around Dhaka city. BJSIR 43(2):273-276

Prescott LM, Harly JP, Kleen DA (2002) Food Microbiolgy, 5th edn. McGraw Hill Book Co., New York, pp 352-627

Rashed N, Md A, Md U, Azizul H, Saurab KM, Mrityunjoy AM, Majibur R (2013) Microbiological study of vendor and packed fruit juices locally available in Dhaka city, Bangladesh. Int Food Res J 20(2):1011-1015

Ryu JH, Beuchat LR (1998) Influence of acid tolerance responces on Survival, growth and crossprotection of Escherichia Coli 0157: Media and fruit juices. Int. J Food Microbiol 45:185-193

Samonis G, Karageorgopoulos DE, Kofteridis DP, Mattaiou DK, Sidiropoulou V, Maraki S, Falagas ME (2009) Citrobacter infections in a general hospital: characteristics and outcomes. Eur J Clin Microbiol Infect Dis 28(1):61-68

Sandeep MD, Waker A, Abhijit G (2001) Microbiological Analysis of street vended fresh squeezed carrot and kinnow-mandarin juices in Patiala city, India. Internet J Food Safety 3:1-3

Sivapalasingam S, Friedman CR, Cohen L, Tauxe RV (2004) Fresh produce: a growing cause of outbreaks of food borne illness in the United States, 1973 through 1997. J Food Prot 67:2342-2353

Tasnim F, Hossain MA, Nusrath S, Hossain MK, Lopa D, Haque KMF (2010) Quality Assessment of Industrially Processed Fruit Juices Available in Dhaka City, Bangladesh. Malaysia J Nutri 16(3):431-438

Vojdani JD, Beuchat LR, Tauxe RV (2008) Juice-associated outbreaks of human illness in the United States, 1995 through 2005. J Food Prot 71(2):356-364

\section{Submit your manuscript to a SpringerOpen ${ }^{\mathcal{D}}$ journal and benefit from:}

- Convenient online submission

Rigorous peer review

- Immediate publication on acceptance

- Open access: articles freely available online

- High visibility within the field

- Retaining the copyright to your article

Submit your next manuscript at $>$ springeropen.com 